\title{
Cronos Devorando al Otoño, Su Hijo Descomunal*
}

1968-1975: siete años le hicieron falta a Gabriel García Márquez para componer y escribir su última novela, El otoño del patriarca, aunque no para imaginarla, ya que, según sabemos, la viene elaborando desde mucho tiempo, como prueba el hecho de que la anunciaba'antes de la publicación de Cien años de soledad(1967):

Dice Garcia Márquez que ha querido siempre escribir un libro sobre un dictator latinoamericano sentado en su palacio, aislado del mundo, con un poder absoluto por el que sienten un terror mortal sus súbditos mistificados y superticiosos. Se preocuparía menos por los efectos sociales que por la patología del personaje. ${ }^{1}$

En 1966 ya estábamos al tanto de la trama narrativa, la cual, como no ha cambiado, nos ahorra el trabajo de resumirla ahora (desde el punto de vista crítico, ésta es la primera inversión cronológica). Tampoco ha cambiado el título, El otoño del patriarca, tantas veces repetido en las preguntas de los admiradores del novelista colombiano. Pero lo que sí cambió desde "los tiempos de gloria" de Cien años de soledad fue el concepto de forma en la que debía de plasmarse la anécdota hasta modificar sustancialmente el plan primitivo:

[.. ]El otoño del patriarca [...] "no será, como suponía”, dice García Márquez [...] " un libro muy largo, sino apenas más largo que $E l$ coronel. No sé por qué no se me había ocurrido antes: debe ser el largo monólogo del dictador en el momento de ser juzgado por un tribunal popular. Estoy trabajando en las notas. ",2

Mediaron entre el proyecto y el humorístico "por fin terminado" final (p. 271) no

*Gabriel García Márquez, El otono del patriarca (Buenos Aires: Editorial Sudamericana, 1975).

1 Luis Harss, "Gabriel García Márquez o la cuerda floja", Mundo Nuevo, Núm 6, dic. 1966, p. 73. Sigue la cita: "Incluso ya le dedicó cuatrocientas páginas al tema en cierta ocasión, pero las rompió porque no se sentía listo todavia para la tarea. No se podía acercar lo suficiente al hombre. Queria hacer un retrato interior, pero no encontró la entrada. Desde entonces ha estado aplazando el proyecto, aunque no indefinidamente. Lo que necesita es un ángulo, uná perspectiva." Todos datos preciosísimos 'para un estudio de la génesis de la novela.

2! Ibid., p. 77. 
sólo el fabuloso éxito de Cien años de soledad, sino, y sobre todo, la voluntad de romper con el ciclo de Macondo, la búsqueda de una nueva escritura que se advierte en los experimentos estilísticos de La increíble y triste bistoria de la cándida Eréndira y de su abuela desalmada (1972) y también el mismo proceso de escribir una novela que, ahora lo sabemos, puede alterar un diseño literario por bien pensado que sea.

Al terminar la lectura de la obra, nos enteramos de que ya estaba contenida potencialmente en la primera frase (posiblemente, sea dicho de paso, la más corta de todo el libro):

Durante el fin de semana los gallinazos se metieron por los balcones de la casa presidencial, destrozaron a picotazos las mallas de alambre de las ventanas y removieron con sus alas el tiempo estancado en el interior, y en la madrugada del lunes la ciudad despertó de su letargo de siglos con una tibia y tierna brisa de muerto grande y de podrida grandeza. (p. 5)

Sólo queremos destacar de este texto el elemento más trascendente para la interpretación de la novela, o sea el punto de vista cronológico. En el texto citado, tanto como en el conjunto novelístico, se nos traslada de súbito de un instante preciso ("el fin de semana", "la madrugada del lunes") hacia lo infinito temporal, la a-cronología de la eternidad ("el tiempo estancado', " "su letargo de siglos" '), para volver luego a cualquier momento fijado por el novelista (el "entonces", de la frase que sigue la cita). Este movimiento de ida y vuelta perpetua, que funciona--y hace funcionar--al nivel de la microestructura textual, rige también la macroestructura del relato. Sin embargo, a este nivel el juego de adelantos-retrocesos se conforma con reglas bastante rígidas dictadas por el escritor. El otoño del patriarca se compone de seis fragmentos (prefiero aquí esta palabra a la de "capítulos'), y todos remiten, en sus respectivos comienzos, al momento del descubrimiento del verdadero cadáver del dictador, aunque a medida que avancemos en nuestra lectura, también vamos acercándonos al presente de la escritura: asi, al principio del fragmento VI presenciamos "la ceremonia de exhibición"' del cadáver preludio a los funerales. A partir de este punto relativamente fijo, involuciona el relato de cada fragmento hacia el pasado, desarrollando un episodio de la vida del patriarca siempre alejado del momento de su verdadera muerte. Asi, el fragmento I cuenta principalmente la historia del "doble" del tirano, su muerte, el descubrimiento de su cadáver: temporalmente topamos con el primer límite de las vísperas o principios del otoño del patriarca, ya que los larguísimos años anteriores, desde los orígenes del régimen, sólo se conocen por alusiones breves. Los fragmentos siguientes, surgidos del mismo punto de partida, relatan à rebours los principales momentos de dicho otoño con sus "tiempos de gloria" y sus "malos tiempos", hasta la edad de la "'decrepitud"' absoluta, objeto del fragmento VI.

Por supuesto, dentro de cada fragmento no se narra un solo episodio sino que incesantemente se pone en marcha el vaivén cronológico que nos hace saltar sea hacia el pasado, sea hacia el futuro con respecto al principal corte temporal del pasaje. El relato, pues, procede por desarrollos sucesivos de momentos antes aludidos o ya más ampliamente evocados, los cuales desempeñarán la función de hitos cronológicos en lo que sigue. El novelista se toma la libertad de abrir grandes huecos narrativos, cuando y donde lo quiere, comprometiéndose a llenarlos conforme al esquema que estructura su obra. Este también exige que el final de cada fragmento se anude con su principio, o sea, según los casos, con el 
período que abarca la muerte del patriarca hasta la ceremonia de la exhibición. ${ }^{3}$

Por lo tanto, podemos deducir (los críticos, pero desde el puntojde vista del narradordios se trata del proceso inverso) el esquema cronológico-narrativo de El otoño del patriarca:

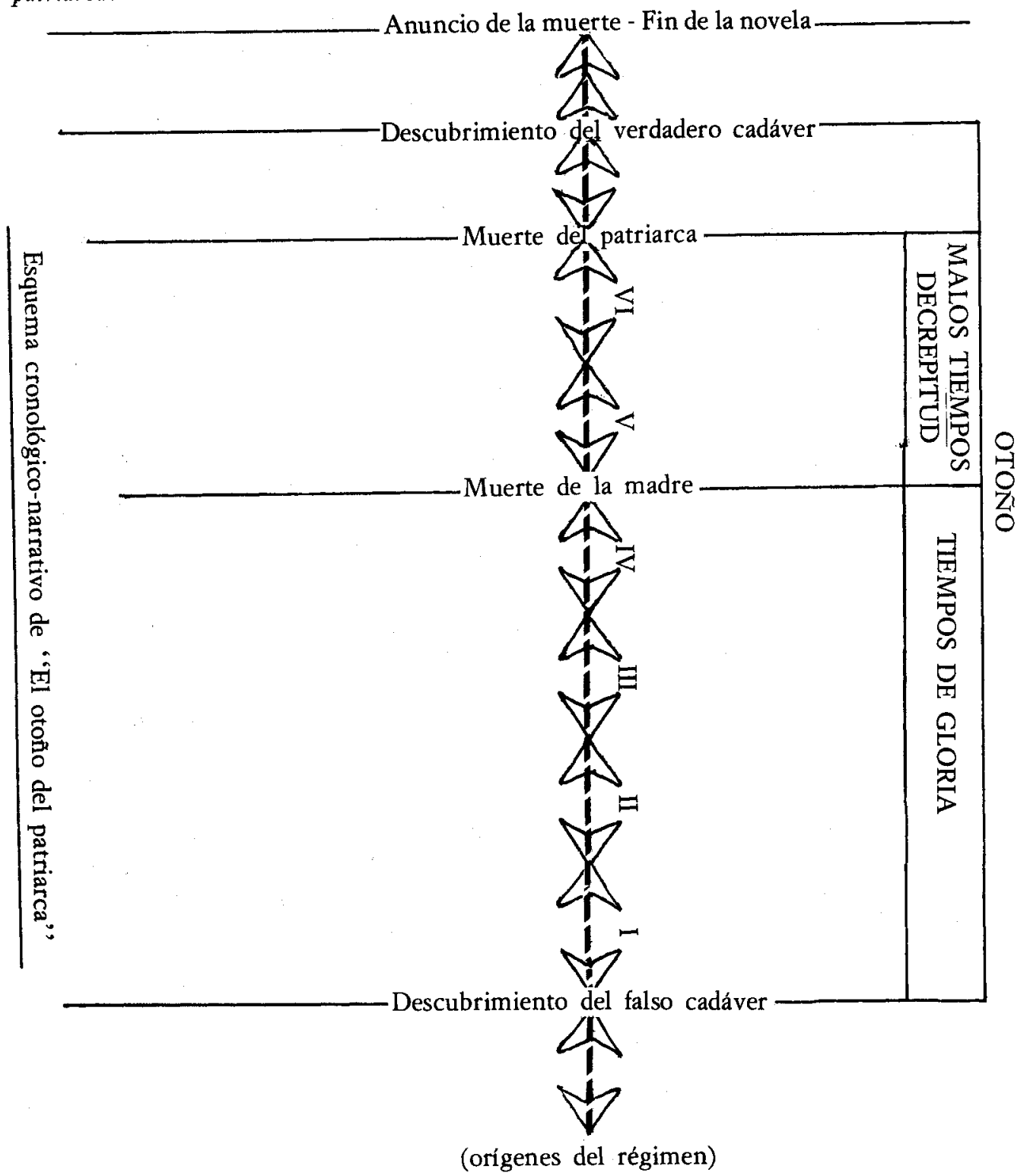

${ }^{3}$ Con excepción, bastante inexplicable, del final del fragmento III (pp. 126-127) que cuenta la muerte y descuartizamiento del general Rodrigo de Aguilar, que ocurren, según un recorte cronológico posterior, en los “últimos tiempos de sus tiempos de gloria"' (p. 242). 
Por supuesto este esquema no es sino una aproximación que ha de completarse mediante la integración de los diagramas propios de cada fragmento, lo que con los múltiples vaivenes temporales daría un gráfico complicadísimo, pero, sin duda alguna, muy interesante.

El tiempo que estructura firmemente la novela también moldea la figura del personaje central, dándonos la clave interpretativa de su patología. Nunca alcanzaremos un retrato físico completo y definitivo del patriarca, sino que se nos impone una visión fragmentada, fluctuante según la edad supuesta del mismo y siempre diversa según el punto de vista narrativo ("nosotros" y "yo" múltiples, narrador-dios, etc.) Un núcleo caracterizador de tres elementos sólo permite la identificación y asegura la permanencia de la figura mediante la fórmula iterativa de "los ojos tristes, los labios pálidos, la mano pensativa" (p. 8) o "los ojos taciturnos, [...] los labios pálidos, la mano de novia sensitiva con un guante de raso"' (p. 14). La pregunta surge, pues, con los súbditos del dictador, si un personaje de tan vagos y movedizos contornos tiene una existencia real, si es un producto de la imaginación. Desde luego, si existiera, tendría un nombre que permitiese identificarlo como ser humano vivo. Pero no lo tiene. Sólo se logra conocer el de su madre, Bendición Alvarado, ${ }^{4}$ aunque tampoco "debía de ser su nombre de origen"' (p. 152). Este fantasma sin nombre se desvanece aun más en la personalidad de su doble, quien lleva el nombre de Patricio A ragonés. ¿Quién es quién? ¿Quién actúa? ¿El patriarca o su doble? ¿No serán una sola persona? ¿No serán nadie? Su ya dudosa existencia parece bucear en la nada al presentarse como "una mano de nadie" (pp. 19-20) o "sin origen" (p. 247), como un "presidente de nadie" (p. 29). Este "hombre sin padre" (p. 51), este "hijo de nadie que llegó a ser rey" (p. 139), ni siquiera tiene existencia oficial, ya que:

parecia imposible demostrar su identidad [la de Bendición Alvarado] porque en los archivos del monasterio donde la habían bautizado no se encontró la hoja de su acta de nacimiento y en cambio se encontraron tres distintas del hijo y en todas era él tres veces distinto, tres veces concebido en tres ocasiones distintas, tres veces parido mal por la gracia de los artífices de la historia patria que habian embrollado los hilos de la realidad para que nadie pudiera descifrar el secreto de su origen, el misterio oculto [...] (pp. 152-153).

Total: tres personas en una sola, algo asi como el misterio de la Santísima Trinidad. El dictador tiene todas las trazas de ser Dios; es nuevo Cristo y Mesías, mientras su madre es, por supuesto, espejo de la Virgen María (cfr. p. 51). La naturaleza le obedece como al Creador del Génesis:

[...]la mano pensativa [...] hacía señales de cruces de bendición para que cesaran las lluvias y brillara el sol, y devolvió la vida a las gallinas ahogadas, y ordenó que bajaran las aguas y las aguas bajaron (p. 104).

Dios Padre, tenía que llamar a su hijo Emanuel, " "que es el nombre con que los otros dioses

\footnotetext{
4.El apellido Alvarado es, quizá, referencial: remite a Pedro de Alvarado, conquistador, compañero de Cortés, de pésimo recuerdo entre los mexicanos. Notemos también que el nombre de la mujer del patriarca, Leticia, es el de la madre de Napoleón.
} 
conocen a Dios"' (p. 177); Dios Hijo, su vida y muerte ya están escritas en profecías y predicciones que todas se realizan mientras el fin de su reino terrestre, piensan todos, "había de destruir los principios de la cristiandad e implantar los orígenes del tercer testamento"' (p. 84); Dios Espíritu Santo, baja a la tierra de los hombres de manera imprevista y portentosa. Así como ocurre con Dios, hay "motivos para dudar de su existencia" (p. 89), pero ¿qué le importa?: siendo eterno, decreta que "el mundo es eterno" (p. 91) y lo "manda por los siglos de los siglos" (p. 140).

Pero, consabido es, si Dios creó a los hombres, los hombres inventaron a Dios. Son ellos los que divinizan al patriarca,

pues lo único que nos daba seguridad sobre la tierra era la certidumbre de que él estaba allí, invulnerable a la peste y al ciclón, invulnerable a la burla de Manuela Sánchez, invulnerable al tiempo, consagrado a la dicha mesiánica de pensar para nosotros [...] (p. 106).

Son "los aduladores impávidos [quienes] lo proclamaban el eterno" (p. 123). Por eso su divinidad es inexistente y su eternidad un engaño según lo afirma la fórmula paradójica del anuncio de su muerte, que cierra el libro:

anunciaron al mundo la buena nueva de que el tiempo incontable de la eternidad habia por fin terminado (p. 271).

El usurpador no es sino un pobre hombre mortal, víctima del proceso de mitificación engañosa que ha puesto en marcha un dictador cualquiera que ya no es dueño de su poder, incapaz de apagar el histerismo colectivo que le encarcela. El patriarca cae en el infierno de los seres que quisieron parecerse a Dios:

no había otra patria que la hecha por él a su imagen y semejanza con el espacio cambiado y el tiempo corregido por los designios de su voluntad absoluta, reconstituida por él desde los origenes más inciertos de su memoria $[\ldots]$ (p. 171).

Todos los mitos que ha ido creando o que iban imaginandolos súbditosen torno a su persona se desbaratan: el cadáver incorrupto de su madre no es sino un engaño; el mismo patriarca no es hijo del Espíritu Santo sino el de un fugitivo de origen desconocido; su patria descomunal no es sino "el reino de la pesadumbre". La edad de su muerte, "entre los 107 y los 232 años"' (p. 87), que por lo extraordinario de los extremos y la misma vaguedad pareceria integrar la esfera de lo imaginario mítico, adquiere carácter de realidad evidente mediante un cálculo aritmético que impone su racionalidad dentro de la irracionalidad de una predicción (p. 97). El otoño del patriarca es la historia de un asalto fracasado a la Eternidad, historia descomunal, por supuesto, que se vincula con el concepto de la ubris griega y, desde luego, con mitos entre los más viejos de la humanidad. Como en éstos, la desmesura se paga, y se paga caro. El tributo del patriarca no es el sólo fracaso de su intento demoníaco sino también la soledad: llora solitario (p. 53), tiembla "ante la idea de encontrarse solo entre la gente de los sueños" (p. 64), está enfermo de soledad cuando una amante lo abandona (p. 72). 
se sintió más viejo que Dios en la penumbra del amanecer de las seis de la tarde de la casa desierta, ${ }^{5}$ se sintió más triste, más solo que nunca en la soledad eterna de este mundo $[\ldots]$ (p. 86).

Por lo tanto cambia de signo: "el transcurso de[los] años incontables"' de su vida (p. 270) ya no es ni un mito ni una realidad maravillosa sino alargamiento intolerable de una soledad sin remedio:

la vida sigue, Leticia, la vida imprevisible de la única de sus tantas mujeres que lo había conseguido todo de él menos el privilegio fácil de que amaneciera con ella en la cama, pues él se iba después del último amor, colgaba la lámpara de salir corriendo en el dintel de su dormitorio de soltero viejo, pasaba las tres aldabas, los tres cerrojos, los tres pestillos, se tiraba bocabajo en el suelo, solo y vestido, como había hecho todas las noches antes de ti, como lo hizo sin ti hasta la última noche de sus sueños de ahogado solitario (pp. 190-191).

De lo dicho hasta ahora se desprende que El otono del patriarca sigue siendo obra de un escritor "deicida", ${ }^{6}$ y más deicida que nunca ya que el tema básico de la novela, según pienso, es la muerte de Dios, dueño del Tiempo, o sea la agonía de Cronos. Como tal, es novela alegórica de múltiples significaciones. En ella se nos representa la lucha imposible por conquistar una eternidad ilusoria y absurdamente arraigada en el corazón y el cuerpo del hombre, tanto más si éste es escritor cuya ambición más alta aspira a ser, como el patriarca, dueño del Tiempo. Con respecto a la carencia de una identidad segura del dictador 7 y a los engaños perpetuos de que es víctima, aunque se crea todopoderoso, esta novela podría ser una grotesca metáfora de la esencia del poder. El poder, nos dice Gabriel García Márquez, no es sino una prisión, "un cautiverio recíproco" (p. 227), una quimera, un juguete para viejos decrépitos, un cetro de latón para un "monarca ilusorio" (p. 220). De ahí que la alegoría desemboque en una filosofía de la vida sencillísima (quizá simplista) que contrasta con lo portentoso de la historia :

descubría en el transcurso de sus años incontables que la mentira es más cómoda que la duda, más útil que el amor, más perdurable que la verdad, había llegado sin asombro a la ficción de ignominia de mandar sin poder, de ser exaltado sin gloria y de ser obedecido sin autoridad cuando se convenció en el reguero de hojas amarillas de su otoño que nunca había de ser el dueño de todo su poder, que estaba condenado a no conocer la vida sino por el revés, condenado a descifrar las costuras y a corregir los hilos de la trama y los nudos de la urdimbre del gobelino de ilusiones de la realidad $[\ldots]$ (p. 270).

A nivel de interpretación socio-mítica, bien puede El otoño del patriarca considerarse como la última visión del mundo latinoamericano que García Márquez va construyendo, según

\footnotetext{
5 El palacio presidencial también es llamado "la casa de soledad" (p. 139).

${ }^{6}$ Cfr. Mario Vargas Llosa, Garcia Márquez, bistoria de un deicidio (Barcelona: Seix Barral, 1971).

${ }^{7} \mathrm{He}$ aquí otra paradoja: sólo cuando ha muerto, es decir cuando es un no-existente, se puede creer en él como ser existente (véase p. 219).
} 
algunos críticos, capa|tras capa, desde sus primeras obras publicadas. En efecto, parece que "este gente sin historia que no cree en nada más que en la vida"' (p. 159), el pueblo de súbditos del patriarca, que de vez en cuando es el propio narrador, puede identificarse fácilmente con todo el pueblo de América Latina. Difícilmente podria rechazarse esta interpretación al considerarse que el dictador va buscando sus propios orígenes en el mismo momento del descubrimiento de América por Cristóbal Colón, superponiendo la imagen de las tres carabelas a la de una invasión de tropas norteamericanas (pp. 44-46, 125, 179, 249).

El espacio concedido a esta nota no me permite señalar otros caminos de aproximación a la sustancia y forma de esta última novela de Gabriel García Márquez. Sólo quisiera subrayar que cualquier estudio de ella no podrá eludir el análisis estilístico. Todo un universo separa "el giro breve, conciso, lapidario y cristalino que va derecho al grano" $/ 8$ de los primeros cuentos de García Márquez de la frase consecuentemente descomunal de la actual novela, que se acerca más al estilo "intestinal" de Joyce, según la terminología de C. G. Jung. ${ }^{\mid} \mid$Pudimos sospechar y seguir esta renovación estilística al leer algunos cuentos de' Eréndira, observando "la voluntad de experimentación|formal que delatan." ' 10

Lo que más sorprende al lector es, por supuesto, la amplitud de la frase, como si lo desmedido del tema hubiera necesitado un estilo desmedido, jadeante, casi sin pausa, tal un ró grande que lo arrastra todo, llevándose consigo los escombros de un reino increíble. En El otono del patriarca la frase constituye una unidad ritmico-narrativa que puede asimilarse a la estrofa de un poema o, mejor a la copla de un cantar épico. Con ella empieza un episodio, con ella se termina: véase, entre todos los ejemplos que es posible aducir, la frase que abarca la agonía y muerte del doble del patriarca (pp. 27-30), buena muestra de realización paródica para una antología esperpéntica. Es de notar que el fragmento VI (pp. 219-271) es una sola cláusula que ha de leerse sin parar. La nueva escritura de García Márquéz se caracteriza también por el empleo (sin medida!) de imágenes y toda clase de figuras retóricas. Se destacan la enumeración, la acumulación, la anáfora. Apuntemos, por ejemplo, la repetición obsesiva del verbo ver en múltiples casos (pp. 5-6, 32-33, 104, $130 ; 220,228,246$, etc.), lo que, por otra parte, podría dar lugar a una interpretación nueva de la novela al nivel semántico. No hablo de la copia metafórica ya bien conocida por las obras anteriores de Garcia Márquez; sólo sefralo que la corriente de imágenes parece acrecentarse en ésta hasta alcanzar una plenitud barroca.

Ahora bien, hay que subrayar la perfecta homogeneidad del nuevo estilo del novelista colombiano. Lo ha pensado todo, pesado, calculado hasta la menor coma, mientras el lector se sumerge en un discurso literario de imaginación rebosante que parece--pero sólo parece--espontáneo. Sin embargo, una lectura más atenta desmonta rápidamente-demasiado rápidamente--los mecanismos y trucos de una escritura que difícilmente oculta sus secretos. 11

B Ernesto Volkening, “'Los Cuentos de GGM o el Trópico Desembrujado" en Gabrièl Garcia Márquez, Isabel viendo llover en Macondo, (Buenos Aires: Ed. Estuario, 1969), p. 27.

9 Véase ibid:

${ }^{10}$ Mario Vargas Lłosa, op. cit., p. 640.

${ }^{11}$ Solo un ejemplo: una metáfora espléndida, "las telarañas de la siesta" (p. 66), se deșvirtúa al repetirse en "las telarañas del duelo"' (p. 146). 
Tampoco faltarán estudios comparativos que sitúen El otoño del patriarca en donde corresponda de la narrativa hispanoamericana y dentro de la propia obra del colombiano. Se trata de "una novela de la dictadura": como tal los criticos nos traerán a la memoria una cantidad de recuerdos, reminiscencias y coincidencias curiosos. Se probará, por ejemplo, que es evidente la presencia de $E l$ señor presidente de Asturias hasta en detalles como la tropa de ciegos, leprosos y mendigos en la Plaza de Armas, frente al palacio presidencial. Aun más asombroso resultará el cotejo con el reciente Recurso del método (1974) de Alejo Carpentier, puesto que se trata de dos obras elaboradas al mismo tiempo, independientemente claro está, las cuales, sin embargo, ofrecen puntos de contacto realmente extraordinarios, tanto al nivel de las representaciones arquetípicas como el tono. $\mathrm{Y}$, desde luego, vendrán también trabajos que traten de valorar El otoño del patriarca en relación con Cien años de soledad. Quizás no tenga mucho sentido este tipo de comparación, siempre subjetiva. Más valdrán los que seffalen la continuidad, sea en superficie, ${ }^{12}$ sea en estructura profunda, de la novelística de Gabriel García Márquez. También tendrán que senalar los puntos de ruptura, ya que $E l$ otoño del patriarca puede definirse, otra vez paradójicamente, como retorno al pasado del escritor y salto hacia el porvenir literario del mismo, arraigo en la tradición literaria de la novela de la dictadura y desprendimiento con respecto a ella, imaginación sin límites y rigor casi matemático de la estructura, mito e historia, asedio a la eternidad y desmoronamiento en la muerte.

Université d' Anvers (Belgique)

JACQUES JOSET

12 A este nivel doy una sola muestra: la persistencia de algunos nombres propios: Prudencio Aguilar (C.A.S.) y Rodrigo de Aguilar (O.P.), Ursula Iguarán y Dionisio Iguarán, Apolinar Moscote y Delfina Moscote, presencia de la figura ahora casi totémica de Sir Walter Raleigh o la del Sumo Pontifice. 